\title{
The Influence of Noble Culture Teaching on the English Ability of Engineering Students
}

\author{
Lihuang Liu \\ School of International Studies, Jingdezhen Ceramic Institute \\ Jingdezhen City, Jiangxi Province, China \\ Email:55588776@qq.com
}

Keywords: English teaching; Noble culture; Appropriateness; Strategy; Wealth and rank culture

\begin{abstract}
The English ability of engineering students is greatly affected by the lack of English cultural background knowledge. It can help to resolve this shortcoming to a certain extent to integrate noble culture teaching into the English cultural background knowledge teaching. This article aims at analyzing the importance of noble culture in the English teaching of engineering students and the specific application strategy of noble culture in English teaching. This article points out a problem existed in the English teaching of engineering students that the particularity of engineering students and the effect of noble culture on English are generally ignored. In addition, this article analyzes the important effect of noble culture on the appropriateness of the engineering students' words and actions in an English speaking environment, explains the specific application ways of noble culture in the English teaching of engineering students and gives a conclusion that noble culture teaching is very important for the acquisition of language skills of engineering students.
\end{abstract}

\section{Problem Existing in the English Teaching of Engineering Students}

There is great particularity in the aspect of English study of engineering students that they generally take English as a tool of study and research and ignore the effect of cultural factors on English using because of the lack of English cultural background knowledge. But in the current English teaching in our country, only few English teachings of engineering students are viewed separately to make up for the shortcoming of lacking English cultural background knowledge according to this particularity.

In domestic college English teaching, there is also not enough attention paid to the English culture teaching. The English language teaching in China should be carried out based on culture, especially the culture with greater influence. Noble culture is a typical English culture, the comparative teaching of noble culture should be particularly carried out in language teaching. But it is the actual situation that noble culture teaching is generally ignored in teaching. Noble culture is completely abandoned and rarely mentioned in English teaching in China because of the unreasonable factors of advertising extravagance and enjoyment and the unfair factors of advertising status privileges and exploitation it contains.

The above highlight a serious problem existed in the English teaching of engineering students that the typical cultural background and the noble culture greatly affect the understanding and using of English are completely ignored because of the neglection of the particularity of English study of engineering students. The inappropriate behaviors of engineering students in social occasions in English speaking countries are the direct result of this problem.

\section{Necessity of Noble Culture for English Teaching}

Noble culture has far-reaching influence in Western countries. Good manners, gentle speech and exquisite tastes of members of the nobility have a great effect on the people's living habits and the patterns of dressing and behavior in the English speaking countries. Noble culture even greatly 
affect the using of English language of people, especially the selection of vocabulary and sentence pattern. So to speak, noble culture influence English language everywhere. Language is the carrier of culture. The birth and using of language are inseparable from the special historical and cultural background of a country or region. Noble culture has affected the English speaking countries for centuries must be embodied in English language. Noble culture teaching is very necessary for the appropriate speech and deportment of engineering students lack the English background knowledge in an English environment.

\section{Noble Culture Affect the Appropriateness of the Using of English.}

The specific effects of noble culture on the using of English are mainly embodied at three aspects. Firstly, the loan words closely connected with French are habitually used as the formal English because of the effects of noble culture. For example, the word "begin" is often used in daily English, and the word "commence" is often used in the formal occasions. In addition, long words are habitually used in the formal occasions, for example, the word "introduce" is often used in daily English, and the long word "introduction" is often used in the formal occasions. The word "talk" can be used in daily communication, and the word "conversation" should be used in the serious occasions. In the questionnaire survey with 200 engineering graduates of Jingdezhen Ceramic Institute of 2013 as the studied objects, only 11 percent of the engineering students can distinguish and use these words. Secondly, noble culture bring some new vocabularies for English. Since the conqueror William ruled England, noble culture had new changes, and it also brought some new vocabularies for English such as ballet, luncheon and etiquette which greatly improved the expression ability of English. Lastly, the rules of etiquette in noble culture has a significant impact on the using of sentence patterns. The sentence patterns used in social occasions by nobles establish the standard for the English sentences used in the formal occasions. These sentence patterns are often very tactful, logical and precise. In the above questionnaire survey, only 5 percent of engineering graduates can distinguish and use these sentences.

In English teaching, if the using of vocabularies and sentence patterns are not deep explained separately, engineering students are likely to use some wrong collocations when they are using English which seriously affect the appropriateness of speech in many occasions.

\section{Noble Culture Affect the Appropriateness of Behaviors in An English Environment.}

People in the English speaking countries have some distinct ceremonies in social contacts because of the effect of noble culture. For example, hand-kissing is a ceremony popular in the upper class society in the English speaking countries. When a man meets a lady, he should cup the lady's fingertips and gently kiss them if the lady offers her hand first and make a slightly drooping motion. If the lady has higher status, the man should bend one of his knees as semi-kneeing first, and then cup the lady's fingertips to kiss them. In addition, engineering students are very strange with the kissing ceremony, embrace ceremony and other ceremonies closely related to noble customs in the English speaking countries. Even for the ceremonies with which engineering students are familiar, they are very particular in the English speaking countries. Shaking hand is also very popular in China. But in the English speaking countries, it is important to note that you can shake their hands only when a guest or a lady offer their hands first, and it is wrong to shake other people's hands when one of your feet is in the door as your another foot is out of the door. The rules of etiquette are very important for the success of social contact, and it is one of the important contexts of the using of language. Engineering students do not understand these rules of etiquette basically.

When the language teaching of engineering students is carried out, it can help students better master the matched using of the words and behaviors in social occasions and make the students be natural and graceful in the contact with the people in the English speaking countries to use noble culture to explain social etiquette. 


\section{Effect of Noble Culture on the Understanding of Social Culture of the English Speaking Countries.}

Noble culture is a window which can help us understand the social culture of the English speaking countries. Noble culture has its own shortcomings and its own shining points. These shining points affect the social culture of the English speaking countries at the following aspects. Firstly, modesty, politeness, elegance, culture and learning represented by the nobility play an exemplary role for people. Secondly, various noble ceremonies fully embody the respect for women and the kindness for others which set an example for the development of the moral character of respecting ceremonies and obeying the law of the modern people in the English speaking countries. Thirdly, noble culture includes the responsibility for country and nation which can greatly help cultivate the patriotism. Fourthly, the new development of noble culture promotes the cultivation of the people's social responsibility in the English speaking country. Developing to today, nobles have been slowly losing their inherited advantages of economic and status. The new peerage is just a kind of honor rewards used to reward the people who have made great contributions to mankind's progress in a particular field. Bill Gates have made great contributions to the development of computer science and always be high on charities, so he was given a peerage by the queen of England. This kind of rewards with title can help to mobilize all positive factors of promoting the social progress to jointly promote the social development. It can be seen that noble culture is a mirror of the social culture of the English speaking countries.

It can not only cultivate the humanistic literacy of engineering students but also cultivate their understanding ability for the social culture and the prejudgment ability for social behavior in an English environment in order to enhance their cultural adaptability to integrate noble culture teaching into English teaching.

For researching the effect of noble culture teaching on the using of English of engineering students, two intact classes of the subject of inorganic nonmetal material of 2012 from Jingdezhen Ceramic Institute are selected for the contrast teaching research as the studied objects. It can be found from the questionnaire survey after two years that the students of the class in which noble culture teaching is integrated into the teaching have obvious improvement in the ability of appropriately using English and social etiquette and the ability of correctly understanding the English culture comparing with another class in which the normal English teaching is adopted.

To summarize, it is not only the need of English teaching's own rules but also the inevitable result of noble culture's own advantages to actively integrate noble culture teaching into the English teaching.

\section{Application Strategy of Noble Culture in English Teaching}

\section{Character Analysis Method in Literary and Audiovisual Works.}

The positive characters created in English literary and audiovisual works are often the characters accord with the aesthetic standards of noble culture. It can help engineering students fully understand the appropriateness of the words and behaviors in social life in the English speaking countries to analyze the words and behaviors express their noble cultural temperament. It can deepen the students' impression and understanding to the taboo behaviors to analyze the words and behaviors of the negative characters created in the literary and audiovisual works. For example, the princess in the movie "Rome Holiday" once represented politeness, nobility and appropriateness in many people's minds, her words and behaviors can fully be the living teaching material help engineering students learn English and understand English culture.

\section{Teaching Method of Critical Absorption.}

In teaching, noble culture should not always be praised and developed. Conversely, we should discuss its advantages and analyze its shortcomings with a fair and objective attitude. The above advantages and new development of noble culture are conductive to the setting of ambitious goals 
and lofty spiritual pursuit of engineering students. At the same time, we should firmly prevent the hedonism color in noble culture from polluting the minds of young students. English language teaching, culture teaching and morality teaching should be complementary to each other and jointly provide services for the comprehensive development of engineering students.

C. Contrast Teaching Method According to the Local Wealth and Rank Culture.

From the prospective of language teaching, the wealth and rank culture and the noble culture can be translation material and target language of each other in translation teaching for more targeted translation teaching and more contrastive culture teaching. At the same time, the wealth and rank culture and the noble culture have significant similarities in many aspects. Both stress the importance of powering the nation and enriching the people and social commitment; the wealth and rank culture advocates "benevolence, righteousness, propriety, wisdom and creditability" which are expressed with different forms in noble culture; Chinese intellectuals in the environment of wealth and rank culture pursue the state of "troubled, improve yourself; valued, improve the world" and pay more attention to their personal culture and social responsibility. The nobles in the environment of noble culture also pay more attention to their own quality and put nation, patriotism and commitment in their hearts. The contrastive application of the two cultures in English teaching will play a complementary role for the cultivation of language application ability of engineering students in a certain cultural background and the shaping of the lofty sentiment of engineering students.

In a word, the contrast teaching with the integration of the noble culture and the wealth and rank culture is not only a effective mean for character education but also a mean for language teaching closely related to culture.

\section{Conclusion}

In conclusion, noble culture teaching is very important for the cultivation of English language ability of engineering students. We can not completely negative noble culture closely related to the people's social life in the English speaking countries. Noble culture is needed in the English teaching of engineering students, because it affects the understanding of engineering students for English culture and the accuracy and appropriateness of English using of engineering students in many aspects. In an English environment, the appropriateness of behaviors and motions of engineering students is also closely related to noble culture. We should absorb the essence and discard the dregs of noble culture in order to service the talents cultivation in our country.

\section{Acknowledgements}

Fund Project: This article is one of the phase achievements of the general project "Research on the Role of Recognition of the Wealth and Rank Culture for Enhancing the Penetration of the Core Values of Chinese Socialism" of the 13th five-year (2016) planned projects of social science of Jiangxi province (project number: 16DQ26).

\section{References}

[1] Li Cheng, Jianhua Cheng. A Comparative Dictionary of English and Chinese Cultures[M]. Changsha, Hunan Education Press, 2000,12.

[2] Liqun Cheng. Survey of the Status of English Culture Teaching of Non-English Majors in Higher Vocational Institutes[J]. Overseas English, 2011(08).

[3] Aichun Ding. Difficulties and Strategies on English Culture Teaching in Higher Vocational Institutes[J]. Communication of Vocational Education, 2011(14).

[4] Yifei Li. Analysis on the Status of College English Culture Teaching[J]. Journal of Hubei Radio \& TV University, 2010(03).

[5] Yu Lv. On the Promotion Function of Culture Displacement for English Grammar Class in Colleges[J]. Journal of Xinxiang University (Social Science Edition), 2010(04). 
[6] Wangbo Shao. Cultural Perspective on Current American Culture[M]. Hefei, Anhui University Press, 1997. 